\title{
Synthesis, Structures, and Solvent-Occlusion Properties of a Molecular Loop and a Molecular Square Using Tetracarbonyl- and Diphosphine-Ligated Diruthenium(I) as Building Blocks and Dicarboxylates as Linkers
}

\author{
Kom-Bei Shiu* and Hong-Chan Lee \\ Department of Chemistry, National Cheng Kung University, Tainan, Taiwan 701 \\ Gene-Hsiang Lee and Yu Wang \\ Instrument Center, National Taiwan University, Taipei, Taiwan 107
}

Received May 6, 2002

\begin{abstract}
Summary: Thereaction of $\left[\mathrm{Ru}_{3}(\mathrm{CO})_{12}\right]$ with malonic acid or oxalic acid, followed by the addition of $\mathrm{PMe}_{3}$, yielded $\left\{\left[\mathrm{Ru}_{2}(\mathrm{CO})_{4}\left(\mathrm{PMe}_{3}\right)_{2}\right]\left(\mu-\mathrm{O}_{2} \mathrm{CCH}_{2} \mathrm{CO}_{2}\right)\right\}_{2}(\mathbf{1})$ and $\left\{\left[\mathrm{Ru}_{2}(\mathrm{CO})_{4^{-}}\right.\right.$ $\left.\left.\left(\mathrm{PMe}_{3}\right)_{2}\right]\left(\mu-\mathrm{O}_{2} \mathrm{CCO}_{2}\right)\right\}_{4}(\mathbf{2})$, respectively. The molecular structures of both $\mathbf{1}$ and $\mathbf{2}$ were determined by single crystal X-ray diffraction to reveal that $\mathbf{1}$ is a molecular loop, while $\mathbf{2}$ is the first example of molecular squares containing $\left\{\mathrm{Ru}_{2}(\mathrm{CO})_{4}\left(\mathrm{PR}_{3}\right)_{2}\right\}$ building blocks.
\end{abstract}

\section{Introduction}

Metal complexes are versatile building blocks in supramolecular chemistry. ${ }^{1}$ The resulted macrocycles usually contain cavities, which are potentially useful for molecule and/or ion recognition. ${ }^{2}$ Recently, active research efforts, especially those of Cotton and co-workers, ${ }^{3}$ using "high-valent"4 metal-metal-bonded dimetallic units such as $\left\{\mathrm{M}_{2}(\text { DaniF })_{2}\right\}^{2+}(\mathrm{M}=\mathrm{Mo}$, Rh; DaniF $=\mathrm{N}, \mathrm{N}^{\prime}$-di-p-anisylformamidinate) as building blocks and di-, tri-, or tetracarboxylate linkers, ${ }^{5-8}$ have produced numerous examples with a variety of interesting geometries, containing cavities of different sizes. In contrast, reports concerning supramolecular arrays based on "low-val ent" units such as $\left\{\mathrm{M}_{2}(\mathrm{CO})_{4}\left(\mathrm{PR}_{3}\right)_{2}\right\}$ are scarce. ${ }^{9}$ The correct choices of subunits and linkers appear critical for the

* To whom correspondence should be addressed. Fax: (+886) 6274 0552. E-mail: kbshiu@mail.ncku.edu.tw.

(1) (a) Fujita, M. Chem. Soc. Rev. 1998, 27, 417. (b) Leininger, S.; Olenyuk, B.; Stang, P. J . 2000, 100, 853. (c) Holliday, B.J .; Mirkin, C. A. Angew. Chem., Int. Ed. 2001, 40, 2022.

(2) (a) Rebek, J. Science 1987, 235, 1478. (b) Melanger, S.; Hupp, J . T. Angew. Chem., Int. Ed. 1999, 38, 2222. (c) Beer, P. D.; Gale, P. A. Angew. Chem., Int. Ed. 2001, 40, 486.

(3) Cotton, F. A.; Lin, C.; Murillo, C. A. Acc. Chem. Res. 2001, 34, 759.

(4) Cotton, F. A. In Inorganic Chemistry toward the 21st Century; Chisholm, M. H., Ed.; ACS Symposium Series 211; American Chemical Society: Washington, DC, 1983; p 209.

(5) (a) Cayton, R. H.; Chisholm, M. H.; Huffman, J . C.; Lobkovsky, E. B. J . Am. Chem. Soc. 1991, 113, 8709. (b) Nelson, K.J .; McGaff, R. W.; Powell, D. R. Inorg. Chim. Acta 2000, 304, 130. (c) Cotton, F. A.; Donahue, J. P.; Murillo, C. A. I norg. Chem. Commun. 2002, 5, 59.

(6) Whelan, E.; Devereux, M.; McCann, M.; McKee, V. Chem. Commun. 1997, 427.

(7) (a) Bornar-Law, R. P.; McGrath, T. P.; Singh, N.; Bickley, J . F.; Steiner, A. Chem. Commun. 1999, 2457. (b) Schiavo, S. L.; Pocsfalvi, G.; Serroni, S.; Cardinao, P.; Piraino, P. Eur. J . Inorg. Chem. 2000, 1371. (c) Bickley, J . F.; Bonar-Law, R. P.; Femoni, C.; MacLean, E. J .; Steiner, A.; Teat, S. J . J . Chem. Soc., Dalton Trans. 2000, 4025.

(8) Bonar-Law, R. P.; McGrath, T. P.; Bickley, J . F.; Femoni, C. Steiner, A. Inorg. Chem. Commun. 2001, 4, 16. success of constructing so-called "molecular loops", "molecular triangles", and "molecular squares". ${ }^{10} \mathrm{H}$ owever, this field of research is still in its infancy, and a detailed understanding is not attainable at present. It is hence not surprising to learn unexpected results from the literature time after time. Notable examples are as follows: (1) an equilibrium in solution is found between the triangle $\left\{\left[\mathrm{Rh}_{2}(\text { DaniF })_{2}\right]\left(\mu-\mathrm{O}_{2} \mathrm{CCO}_{2}\right)\right\}_{3}$ and square $\{-$ $\left.\left[\mathrm{Rh}_{2}(\text { DaniF })_{2}\right]\left(\mu-\mathrm{O}_{2} \mathrm{CCO}_{2}\right)\right\}_{4}$, but not between the unknown triangle $\left\{\left[\mathrm{MO}_{2}(\mathrm{DaniF})_{2}\right]\left(\mu-\mathrm{O}_{2} \mathrm{CCO}_{2}\right)\right\}_{3}$ and the known square $\left.\left\{\left[\mathrm{Mo}_{2}(\text { DaniF })_{2}\right]\left(u-\mathrm{O}_{2} \mathrm{CCO}_{2}\right)\right\}\right\}_{4} ;{ }^{3}(2)$ a square geometry is found for $\left\{\left[\mathrm{Rh}_{2}(\text { DaniF })_{2}\right]\left(u\right.\right.$-trans- $1,4-\mathrm{O}_{2}-$ $\left.\left.\mathrm{CC}_{6} \mathrm{H}_{4} \mathrm{CO}_{2}\right)\right\}_{4}$, but a triangle is found for $\left\{\left[\mathrm{Re}_{2} \mathrm{Cl}_{2}(\mu\right.\right.$ dppm $\left.)_{2}\right]\left(\mu\right.$ - trans- $\left.\left.1,4-\mathrm{O}_{2} \mathrm{CC}_{6} \mathrm{H}_{4} \mathrm{CO}_{2}\right)\right\}_{3} 3^{3}$ (3) a molecular loop is found for $\left\{\left[\mathrm{M}_{2}(\text { DaniF })_{2}\right]\left(u-\mathrm{O}_{2} \mathrm{CCH}_{2} \mathrm{CO}_{2}\right)\right\}_{2}(\mathrm{M}=$ $\mathrm{Mo}, \mathrm{Rh}){ }_{1}{ }^{3}\left\{\left[\mathrm{Mo}_{2}(\mathrm{MeCN})_{6}\right]\left(\mu-\mathrm{O}_{2} \mathrm{CCH}_{2} \mathrm{CH}_{2} \mathrm{CO}_{2}\right)\right\}_{2}{ }^{4+}, 6$ and $\left\{\left[\mathrm{Ru}_{2}(\mathrm{CO})_{4}\left(\mathrm{PBu}_{3}\right)_{2}\right]\left(\mu-\mathrm{O}_{2} \mathrm{CCH}_{2} \mathrm{CH}_{2} \mathrm{CH}_{2} \mathrm{CO}_{2}\right)\right\}_{2}$, 9 a but a molecular triangle is found for $\left\{\left[\mathrm{Ru}_{2}(\mathrm{CO})_{4}\left(\mathrm{PBu}_{3}\right)_{2}\right]\left(\mu-\mathrm{O}_{2^{-}}\right.\right.$ $\mathrm{CCHOHCHOHCO} 2)_{3} .{ }^{9 b}$ Thus, we deemed it important to begin our studies by preparing and structurally characterizing polymetallic supramolecules using the low-valent type of dimetallic building units and simple muticarboxylate linkers as well as other types of linkers. We report herein the synthesis and structures of the molecular loop $\left\{\left[\mathrm{Ru}_{2}(\mathrm{CO})_{4}\left(\mathrm{PMe}_{3}\right)_{2}\right]\left(\mu-\mathrm{O}_{2} \mathrm{CCH}_{2} \mathrm{CO}_{2}\right)\right\}_{2}(\mathbf{1})$ and the molecular square $\left\{\left[\mathrm{Ru}_{2}(\mathrm{CO})_{4}\left(\mathrm{PPh}_{3}\right)_{2}\right]\left(\mu-\mathrm{O}_{2^{-}}\right.\right.$ $\left.\left.\mathrm{CCO}_{2}\right)\right\}_{4}$ (2). The latter is the first square geometry containing $\left\{\mathrm{Ru}_{2}(\mathrm{CO})_{4}\left(\mathrm{PR}_{3}\right)_{2}\right\}$ building units. It is interesting to note that the complexity of the converted product from the reaction of $\left[\mathrm{Ru}_{3}(\mathrm{CO})_{12}\right]$ with a dicarboxylic acid is not parallel to the length between the two carboxyl groups of the dicarboxylic acid used: the reaction product from the acid with a zero-carbon-atom separation is a molecular square such as $\mathbf{2}$, that from the acid with a one-carbon-atom separation is a molecular loop such as 1, that from the acid with a twocarbon-atom separation is a molecular triangle such as $\left\{\left[\mathrm{Ru}_{2}(\mathrm{CO})_{4}\left(\mathrm{PBu}_{3}\right)_{2}\right]\left(\mu-\mathrm{O}_{2} \mathrm{CCHOHCHOHCO}\right)_{2}\right\}_{3}$, and that

(9) (a) Bianchi, M.; Matteoli, U .; Frediani, P.; Piacenti, F .; Nardelli, U.; Pelizzi, G. Chim. Ind. (Milan) 1986, 63, 475. (b) Suss-Fink, G. Wolfender, J .-L.; Neumann, F .; Stoeckli-E vans, H. Angew. Chem., I nt. Ed. Engl. 1990, 29, 429. (c) Rubin, Y.; Knobler, C. B.; Diederich, F. J . Am. Chem. Soc. 1990, 112, 4966.

(10) Cyclic molecules consisting of two, three, or four dimetal units at the corners connected peripherally and sequentially with one dicarboxylate linker are called "molecular loops", "molecular triangles", and "molecular squares", respectively. 
Table 1. Crystal Data

\begin{tabular}{|c|c|c|}
\hline & 1 & $2 \cdot 3 \mathrm{CH}_{2} \mathrm{Cl}_{2}$ \\
\hline $\begin{array}{l}\text { formula } \\
\text { fw }\end{array}$ & $\begin{array}{l}\mathrm{C}_{26} \mathrm{H}_{36} \mathrm{O}_{16} \mathrm{P}_{4} \mathrm{Ru}_{4} \\
1132.71\end{array}$ & $\begin{array}{l}\mathrm{C}_{25.5} \mathrm{H}_{39} \mathrm{Cl}_{3} \mathrm{O}_{16} \mathrm{P}_{4} \mathrm{Ru}_{4} \\
1236.08\end{array}$ \\
\hline temp (K) & $150(1)$ & 15 \\
\hline space & triclinic, $\mathrm{P} \overline{1}$ & monoclinic, $\mathrm{P} 2_{1} / \mathrm{n}$ \\
\hline$a(\AA)$ & $9.7864(1)$ & $13.3878(1)$ \\
\hline$b(\AA)$ & $3(2)$ & 21. \\
\hline$c(\AA)$ & 14. & 15.3 \\
\hline$\alpha$ (deg) & 8 & 90 \\
\hline$\beta$ (deg) & $80.9637(6)$ & $95.2705(4)$ \\
\hline$\gamma$ (deg) & $4(5)$ & 90 \\
\hline $\mathrm{V}, \AA$ & 3(4) & 438 \\
\hline Z & 2 & 4 \\
\hline $\mathrm{D}_{\text {calcd }}, \mathrm{g} \mathrm{cm}^{-3}$ & 1.845 & 1.874 \\
\hline $\mathrm{F}(00$ & 1112 & 2428 \\
\hline $2 \theta \mathrm{r}$ & $2-55$ & $2-55$ \\
\hline$h, k, l$ & $\pm 12, \pm 18, \pm 19$ & $\pm 17, \pm 27, \pm 19$ \\
\hline $\mathrm{mm}^{-1}$ & 1.741 & 1.741 \\
\hline n factors & $0.911-0.683$ & $0.813-0.743$ \\
\hline$\lambda(\mathrm{M}$ & & 0.71 \\
\hline no. & 405 & 30912 \\
\hline bsd rflns ( $\left.\mathrm{N}_{0}\right)$ & $9330(>2 \sigma)$ & $10062(>2 \sigma)$ \\
\hline abs cor & Sadabs & Sadabs \\
\hline refinement program & NRCVAX & NRCVAX \\
\hline no. of ref params $\left(\mathrm{N}_{\mathrm{p}}\right)$ & 452 & 522 \\
\hline $\mathrm{R}^{\mathrm{a}} \mathrm{R}_{\mathrm{w}}{ }^{\mathrm{a}}$ & $0.0414,0.1082$ & $0.0457,0.1165$ \\
\hline GOFa & 1.165 & 1.134 \\
\hline weighting scheme & $\begin{array}{l}{\left[\sigma^{2}\left(\mathrm{~F}_{\mathrm{o}}\right)+\right.} \\
\left.\quad 0.0054 \mathrm{~F}_{\mathrm{o}}^{2}\right]^{-1}\end{array}$ & $\begin{array}{l}{\left[\sigma^{2}\left(\mathrm{~F}_{\mathrm{o}}\right)+\right.} \\
\left.\quad 0.00256 \mathrm{~F}_{0}^{2}\right]^{-1}\end{array}$ \\
\hline
\end{tabular}

from the acid with a three-carbon-atom separation is a molecular loop again such as $\left\{\left[\mathrm{Ru}_{2}(\mathrm{CO})_{4}\left(\mathrm{PBu}_{3}\right)_{2}\right]\left(\mu-\mathrm{O}_{2^{-}}\right.\right.$ $\mathrm{CCH}_{2} \mathrm{CH}_{2} \mathrm{CH}_{2} \mathrm{CO}_{2}$ ) $\}_{2}$.

\section{Experimental Section}

All reactions were performed under prepurified nitrogen using freshly distilled solvents. ${ }^{1} \mathrm{H}$ and ${ }^{31} \mathrm{P}$ NMR spectra were recorded on a Bruker AVANCE 300 spectrometer $\left({ }^{1} \mathrm{H}, 300\right.$ $\mathrm{MHz}$; ${ }^{31} \mathrm{P}, 122 \mathrm{MHz}$ ) calibrated against internal deuterated solvents $\left({ }^{1} \mathrm{H}\right)$ or external $85 \% \mathrm{H}_{3} \mathrm{PO}_{4}\left({ }^{31 P}\right)$. IR spectra were recorded on a Bio-Rad FTS 175 instrument. Microanalyses were carried out by the staff of the Microanalytical Service of the Department of Chemistry, National Cheng Kung University.

Synthesis of $\left\{\left[\mathrm{Ru}_{2}(\mathrm{CO})_{4}\left(\mathrm{PMe}_{3}\right)_{2}\right]\left(\mu-\mathrm{O}_{2} \mathrm{CCH}_{2} \mathrm{CO}_{2}\right)\right\}_{2}(\mathbf{1})$. The freshly prepared ${ }^{11}\left[\mathrm{Ru}_{3}(\mathrm{CO})_{12}\right](0.100 \mathrm{~g}, 0.155 \mathrm{mmol})$, malonic acid $(0.025 \mathrm{~g}, 0.232 \mathrm{mmol})$, and THF $(20 \mathrm{~mL})$ were added in a pressure Schlenk tube. The mixture was heated to $120^{\circ} \mathrm{C}$ while being magnetically stirred for $6 \mathrm{~h}$. To avoid a back-reaction, the gases evolved were drawn off from time to time. $\mathrm{PMe}_{3}$ solution (ca. $0.50 \mathrm{~mL}, 1.0 \mathrm{M}$ solution in THF) was then added. The solution was stirred for $2 \mathrm{~h}$ more, and the solvents were then removed under vacuum, forming a solid residue. Recrystallization from $\mathrm{CH}_{2} \mathrm{Cl}_{2} / \mathrm{MeOH}$ gave $97 \mathrm{mg}$ of $\left\{\left[\mathrm{Ru}_{2}(\mathrm{CO})_{4}\left(\mathrm{PMe}_{3}\right)_{2}\right]\left(u-\mathrm{O}_{2} \mathrm{CCH}_{2} \mathrm{CO}_{2}\right)\right\}_{2}$ (1). Yield $74 \%$. Anal. Calcd for $\mathrm{C}_{26} \mathrm{H}_{40} \mathrm{O}_{16} \mathrm{P}_{4} \mathrm{Ru}_{4}$ : C, 27.47; $\mathrm{H}$, 3.55. Found: C, 27.36; $\mathrm{H}$, 3.58. ${ }^{1} \mathrm{H}$ NMR $\left(\mathrm{CD}_{2} \mathrm{Cl}_{2}\right): \delta 1.53(\mathrm{t}, 36 \mathrm{H}$, J H.P $=3.9 \mathrm{~Hz}$, $\left.\mathrm{P}\left(\mathrm{CH}_{3}\right)_{3}\right), 3.15\left(\mathrm{~s}, 4 \mathrm{H}, \mathrm{O}_{2} \mathrm{CCH}_{2} \mathrm{CO}_{2}\right) .{ }^{31} \mathrm{P}\left\{{ }^{1} \mathrm{H}\right\} \mathrm{NMR}\left(\mathrm{CD}_{2} \mathrm{Cl}_{2}\right)$ : $\delta-11.94$ (s, 4 P). IR $\left(\mathrm{CH}_{2} \mathrm{Cl}_{2}\right): \mathrm{v}_{\mathrm{CO}} 2015 \mathrm{~s}, 1969 \mathrm{~m}, 1942 \mathrm{~s}$ $\mathrm{cm}^{-1}$.

Synthesis of $\left\{\left[\mathrm{Ru}_{2}(\mathrm{CO})_{4}\left(\mathrm{PMe}_{3}\right)_{2}\right]\left(\mu-\mathrm{O}_{2} \mathrm{CCO}_{2}\right)\right\}_{4}$ (2). This compound was prepared similarily from freshly prepared ${ }^{11}$ $\left[\mathrm{Ru}_{3}(\mathrm{CO})_{12}\right]$ and oxalic acid with use of the procedure described for the synthesis of $\mathbf{1}$; yield $73 \%$. Anal. Calcd for $\mathrm{C}_{48} \mathrm{H}_{72} \mathrm{O}_{32} \mathrm{P}_{8-}$ Rus: C, 26.00; $\mathrm{H}, 3.27$. Found: $\mathrm{C}, 25.81 ; \mathrm{H}, 3.37 .{ }^{1} \mathrm{H}$ NMR $\left(\mathrm{CD}_{2} \mathrm{Cl}_{2}\right): \delta 1.48\left(\mathrm{t}, 72 \mathrm{H}, \mathrm{J}, \mathrm{P}=3.9 \mathrm{~Hz}, \mathrm{P}\left(\mathrm{CH}_{3}\right)_{3}\right) .{ }^{31} \mathrm{P}\left\{{ }^{1} \mathrm{H}\right\} \mathrm{NMR}$ $\left(\mathrm{CD}_{2} \mathrm{Cl}_{2}\right): \delta-13.45(\mathrm{~s}, 8 \mathrm{P})$. IR $\left(\mathrm{CH}_{2} \mathrm{Cl}_{2}\right): \mathrm{v}_{\mathrm{CO}} 2020 \mathrm{~s}, 1974 \mathrm{~m}$ $1947 \mathrm{~s} \mathrm{~cm}^{-1}$.

Scheme 1

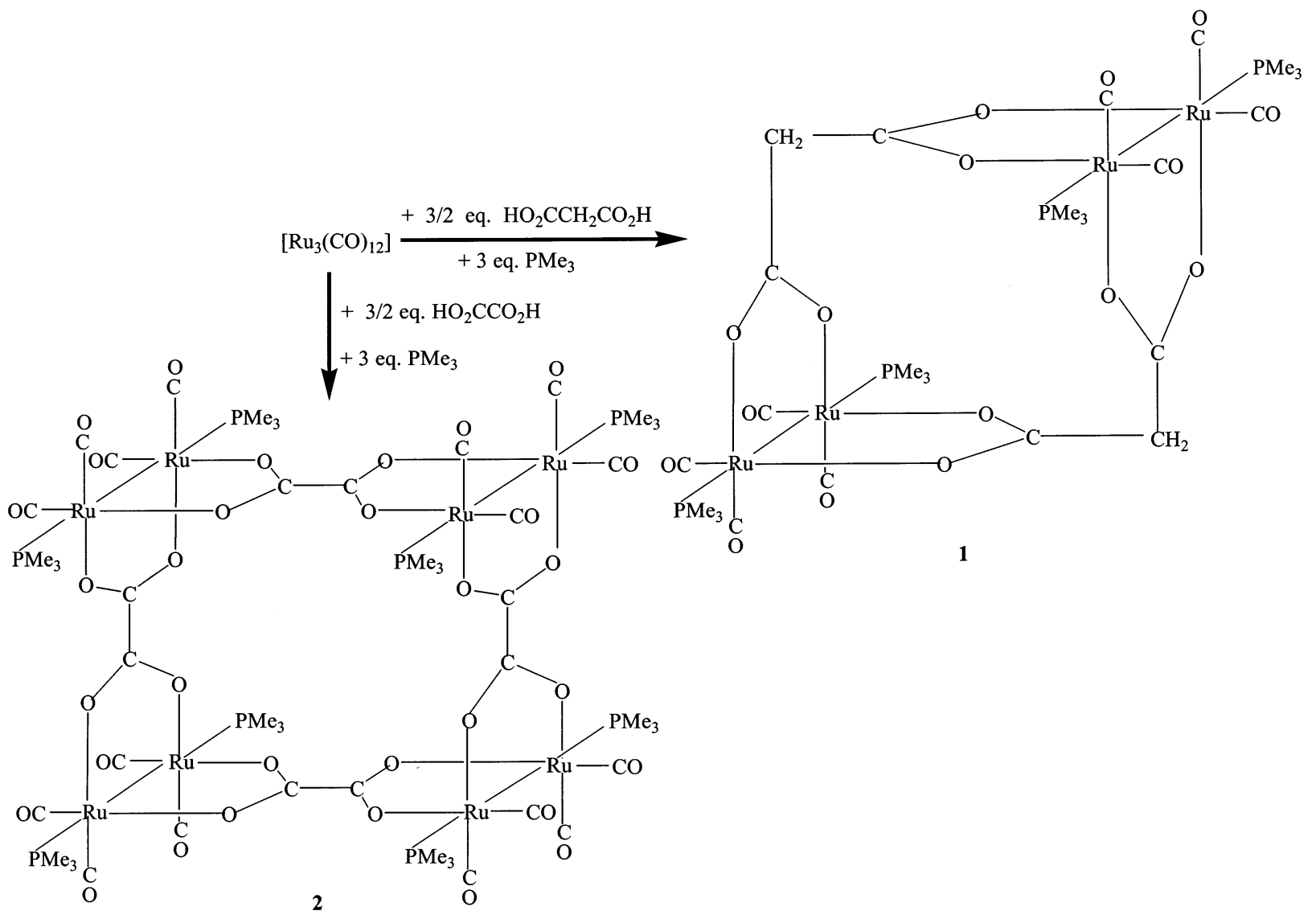




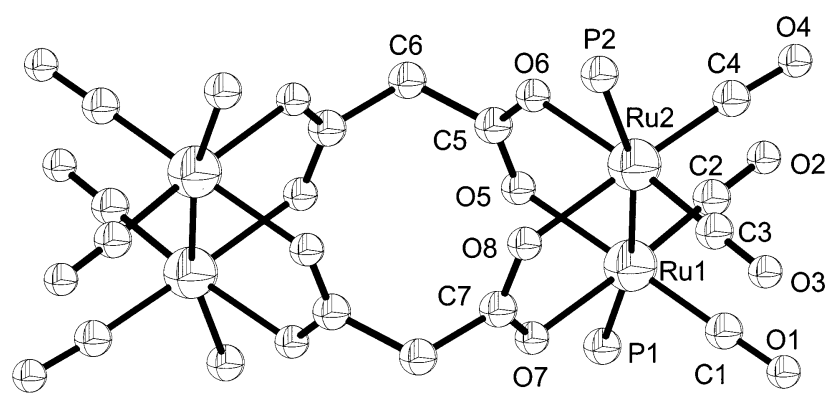

Figure 1. ORTEP plot of the molecular loop 1A with $50 \%$ thermal ellipsoids. All methyl groups and hydrogen atoms are omitted for clarity. An inversion center is imposed crystallographically at the center of the loop. Selected bond lengths $(\AA): \operatorname{Ru}(1)-\operatorname{Ru}(2)=2.7235(5), R u(1)-C(1)=1.839$ (5), $\mathrm{Ru}(1)-\mathrm{C}(2)=1.838(6), \mathrm{Ru}(1)-\mathrm{O}(5)=2.141(3), \mathrm{Ru}(1)-$ $\mathrm{O}(7)=2.151(3), \mathrm{Ru}(1)-\mathrm{P}(1)=2.385(1), \mathrm{Ru}(2)-\mathrm{C}(3)=$ 1.839(5), $\mathrm{Ru}(2)-\mathrm{C}(4)=1.852(6), \mathrm{Ru}(2)-\mathrm{O}(6)=2.130(3)$, $\mathrm{Ru}(2)-\mathrm{O}(8)=2.124(3), \mathrm{Ru}(2)-\mathrm{P}(2)=2.377(1), \mathrm{C}(1)-\mathrm{O}(1)$ $=1.154(7), \mathrm{C}(2)-\mathrm{O}(2)=1.154(7), \mathrm{C}(3)-\mathrm{O}(3)=1.154(6)$, $\mathrm{C}(4)-\mathrm{O}(4)=1.149(7), \mathrm{C}(5)-\mathrm{O}(5)=1.252(6), \mathrm{C}(5)-\mathrm{O}(6)=$ $1.252(6), C(5)-C(6)=1.533(6), C(6)-C(7 A)=1.534(6)$, $\mathrm{C}(7)-\mathrm{O}(7)=1.252(6), \mathrm{C}(7)-\mathrm{O}(8)=1.264(6)$. Selected bond angles (deg): $\mathrm{Ru}(1)-\mathrm{Ru}(2)-\mathrm{P}(2)=166.05(4), \mathrm{Ru}(2)-\mathrm{Ru}-$ $(1)-\mathrm{P}(1)=170.36(4), \mathrm{O}(5)-\mathrm{Ru}(1)-\mathrm{C}(1)=174.9(2), \mathrm{O}(7)-$ $\mathrm{Ru}(1)-\mathrm{C}(2)=176.5(2), \mathrm{O}(6)-\mathrm{Ru}(2)-\mathrm{C}(3)=175.2(2), \mathrm{O}(8)-$ $\mathrm{Ru}(2)-\mathrm{C}(4)=177.9(2), \mathrm{Ru}(1)-\mathrm{C}(1)-\mathrm{O}(1)=179.2(5), \mathrm{Ru}(1)-$ $\mathrm{C}(2)-\mathrm{O}(2)=177.5(5), \mathrm{Ru}(2)-\mathrm{C}(3)-\mathrm{O}(3)=178.9(5), \mathrm{Ru}(2)-$ $\mathrm{C}(4)-\mathrm{O}(4)=175.1(5)$.

Crystallographic Procedures. Data were collected at $150 \mathrm{~K}$ on a Siemens SMART-CCD instrument, equipped with a normal-focus and $3 \mathrm{~kW}$ sealed-tube $X$-ray source. The structures of $\mathbf{1}$ and $\mathbf{2}$ were solved by heavy-atom methods and refined by a full-matrix least-squares procedure using NRCVAX. ${ }^{12}$ All the non-hydrogen atoms were refined anisotropically. The other essential details of single-crystal data measurement and refinement are given in Table 1 . Three $\mathrm{CH}_{2-}$ $\mathrm{Cl}_{2}$ mol ecules were found in the asymmetric unit of the crystal of 2. One $\mathrm{PMe}_{3}$ group exhibits a slight disorder. It was refined as a pair, comprising a major and a minor orientation. The major orientation of the group containing $P(3), C(19), C(20)$, and $C(21)$ had an occupancy of 0.657 . The minor orientation of the group containing $\mathrm{P}\left(3^{\prime}\right), \mathrm{C}\left(19^{\prime}\right), \mathrm{C}\left(20^{\prime}\right)$, and $\mathrm{C}\left(21^{\prime}\right)$ had an occupancy of 0.343 . $\mathrm{Cl}(4)$ has an occupancy of 0.5 .

\section{Results and Discussion}

Following a similar procedure reported for the molecular triangle $\left\{\left[\mathrm{Ru}_{2}(\mathrm{CO})_{4}\left(\mathrm{PBu}_{3}\right)_{2}\right]\left(\mu-\mathrm{O}_{2} \mathrm{CCHOHCHO}-\right.\right.$ $\left.\left.\mathrm{HCO}_{2}\right)\right\}_{3},{ }^{9 b}$ but using freshly prepared $\left[\mathrm{Ru}_{3}(\mathrm{CO})_{12}\right]$, we have obtained a single product, confirmed by ${ }^{31} \mathrm{P}\left\{{ }^{1} \mathrm{H}\right\}$ NMR spectroscopy. Chromatographic separation ${ }^{9 \mathrm{~b}}$ of products is hence not necessary. The reactions produce $\mathbf{1}$ and $\mathbf{2}$ in satisfactory yields (Scheme 1).

The structures of both $\mathbf{1}$ and $\mathbf{2}$ have been established by X-ray crystall ography to reveal that $\mathbf{1}$ is a molecular loop (Figure 1), while $\mathbf{2}$ is a molecular square (Figure 2). Compound 2 represents the first example of molecular squares containing $\left\{\mathrm{Ru}_{2}(\mathrm{CO})_{4}\left(\mathrm{PR}_{3}\right)_{2}\right\}$ building blocks. Two crystallographically independent molecules, $1 \mathrm{~A}$ and 1B, were found in the unit cell. Since $\mathbf{1 A}$ is similar to 1B, only $\mathbf{1 A}$ is shown in Figure 1 . An eclipsed paddlewheel arrangement, with two paddle sets of cis carbo-

(11) J ohnson, B. F.; Lewis, J . Inorg. Synth. 1972, 13, 92.

(12) Gabe, E. J .; Le Page, Y.; Charland, J .-P.; Lee, F. L.; Lee, P. S. J . Appl. Crystallogr. 1989, 22, 384.

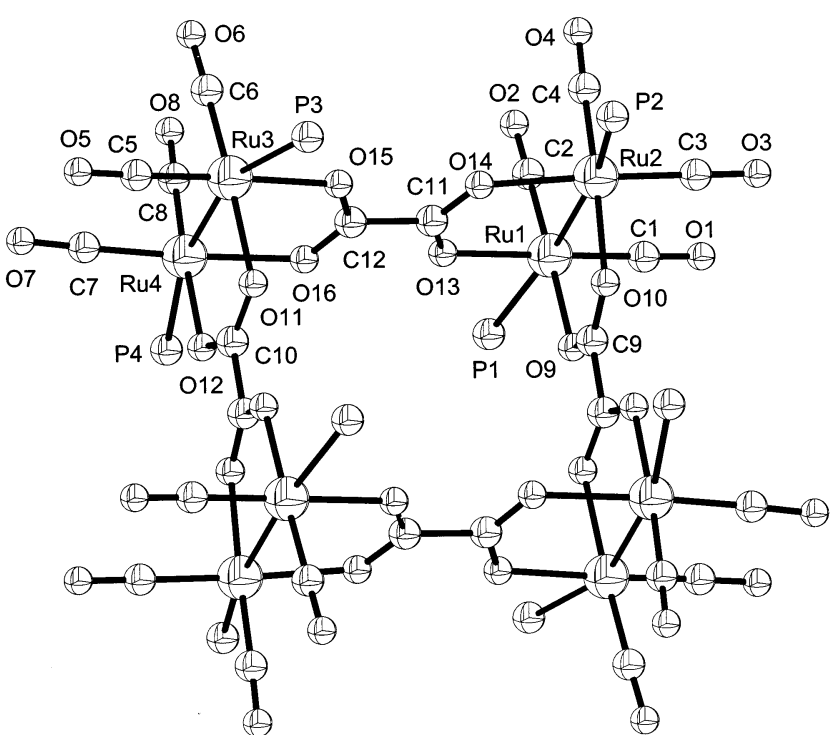

Figure 2. ORTEP plot of the molecular square $\mathbf{2}$ with $50 \%$ thermal ellipsoids. All methyl groups are omitted for darity. An inversion center is imposed crystallographically at the center of the square. Selected bond lengths $(\AA)$ : Ru$(1)-R u(2)=2.7262(6), \mathrm{Ru}(1)-\mathrm{C}(1)=1.846(6), \mathrm{Ru}(1)-\mathrm{C}(2)$ $=1.845(6), \mathrm{Ru}(1)-\mathrm{O}(9)=2.144(3), \mathrm{Ru}(1)-\mathrm{O}(13)=2.139-$ (3), $\mathrm{Ru}(1)-\mathrm{P}(1)=2.377(2), \mathrm{Ru}(2)-\mathrm{C}(3)=1.850(6), \mathrm{Ru}(2)-$ $\mathrm{C}(4)=1.836(6), \mathrm{Ru}(2)-\mathrm{O}(10)=2.150(3), \mathrm{Ru}(2)-\mathrm{O}(14)=$ 2.139(3), $\mathrm{Ru}(2)-\mathrm{P}(2)=2.390(2), \mathrm{Ru}(3)-\mathrm{Ru}(4)=2.720(6)$, $\mathrm{Ru}(3)-\mathrm{C}(5)=1.841(7), \mathrm{Ru}(3)-\mathrm{C}(6)=1.834(6), \mathrm{Ru}(3)-\mathrm{O}(11)$ $=2.156(3), \mathrm{Ru}(3)-\mathrm{O}(15)=2.137(4), \mathrm{Ru}(3)-\mathrm{P}(3)=2.460-$ (3), $\mathrm{Ru}(4)-\mathrm{C}(7)=1.833(5), \mathrm{Ru}(4)-\mathrm{C}(8)=1.843(5), \mathrm{Ru}(4)-$ $\mathrm{O}(12)=2.144(3), \mathrm{Ru}(4)-\mathrm{O}(16)=2.152(3), \mathrm{Ru}(4)-\mathrm{P}(4)=$ 2.376(1), $\mathrm{C}(1)-\mathrm{O}(1)=1.153(7), \mathrm{C}(2)-\mathrm{O}(2)=1.145(6), \mathrm{C}(3)-$ $\mathrm{O}(3)=1.141(7), \mathrm{C}(4)-\mathrm{O}(4)=1.158(7), \mathrm{C}(5)-\mathrm{O}(5)=1.156-$ (8), $\mathrm{C}(6)-\mathrm{O}(6)=1.151(8), \mathrm{C}(7)-\mathrm{O}(7)=1.146(7), \mathrm{C}(8)-\mathrm{O}(8)$ $=1.149(6), \mathrm{C}(9)-\mathrm{O}(9)=1.253(6), \mathrm{C}(9)-\mathrm{O}(10)=1.255(6)$, $\mathrm{C}(10)-\mathrm{O}(11)=1.259(6), \mathrm{C}(10)-\mathrm{O}(12)=1.251(6), \mathrm{C}(11)-$ $\mathrm{O}(13)=1.252(6), \mathrm{C}(11)-\mathrm{O}(14)=1.256(6), \mathrm{C}(12)-\mathrm{O}(15)=$ $1.250(6), \mathrm{C}(12)-\mathrm{O}(16)=1.247(5), \mathrm{C}(9)-\mathrm{C}(10)=1.552(7)$, $C(11)-C(12 A)=1.546(7)$. Selected bond angles (deg): Ru$(1)-R u(2)-P(2)=168.39(4), R u(2)-R u(1)-P(1)=166.80-$ (4), $\mathrm{O}(13)-\mathrm{Ru}(1)-\mathrm{C}(1)=178.5(2), \mathrm{O}(9)-\mathrm{Ru}(1)-\mathrm{C}(2)=$ 177.2(2), O(14)-Ru(2)-C(3) = 176.7(2), O(10)-Ru(2)-C(4) $=176.8(2), \mathrm{Ru}(1)-\mathrm{C}(1)-\mathrm{O}(1)=177.7(5), \mathrm{Ru}(1)-\mathrm{C}(2)-\mathrm{O}(2)$ $=178.6(5), \mathrm{Ru}(2)-\mathrm{C}(3)-\mathrm{O}(3)=179.7(6), \mathrm{Ru}(2)-\mathrm{C}(4)-\mathrm{O}(4)$ $=177.5(5), R u(3)-R u(4)-P(4)=164.02(4), R u(4)-R u(3)-$ $\mathrm{P}(3)=160.0(1), \mathrm{O}(15)-\mathrm{Ru}(3)-\mathrm{C}(5)=178.3(2), \mathrm{O}(11)-\mathrm{Ru}-$ (3) $-\mathrm{C}(6)=176.1(2), \mathrm{O}(16)-\mathrm{Ru}(4)-\mathrm{C}(7)=176.4(2), \mathrm{O}(12)-$ $\mathrm{Ru}(4)-\mathrm{C}(8)=177.0(2), \mathrm{Ru}(3)-\mathrm{C}(5)-\mathrm{O}(5)=178.4(6), \mathrm{Ru}(3)-$ $\mathrm{C}(6)-\mathrm{O}(6)=177.8(6), \mathrm{Ru}(4)-\mathrm{C}(7)-\mathrm{O}(7)=177.6(5), \mathrm{Ru}(4)-$ $\mathrm{C}(8)-\mathrm{O}(8)=177.5(5)$.

nyls and two other sets of equatorial oxalate linkers, is found for each $\left\{\mathrm{Ru}_{2}\right\}$ unit, attached with two axial, eclipsed $\mathrm{PMe}_{3}$ groups, in both $\mathbf{1}$ and $\mathbf{2}$. The Ru' atoms are six-coordinate, and their environments are very similar. The Ru-Ru distances of 2.7235(5) $\AA$ in 1A, 2.7340(5) $\AA$ in 1B, and 2.7262(6) $\AA$ in $\mathbf{2}$ are comparable to the reported single-bond values. ${ }^{13}$ All other bond lengths such as $\mathrm{Ru}-\mathrm{CO}$ and $\mathrm{Ru}-\mathrm{P}$ are also similar, as expected, to the reported values. Each structure has a square cage close to $4.2 \times 4.2 \times 2.7 \AA^{3}$ in 1 and $6.9 \times$ $6.9 \times 2.7 \AA^{3}$ in $\mathbf{2}$ with the axially bonded phosphine ligands serving as lids above and below the cage. The "square" area of ca. $4.2 \times 4.2 \AA^{2}$ is defined by two Ru

(13) Shiu, K.-B.; Peng, S.-M.; Cheng, M.-J . J . Organomet. Chem. $1993,452,143$ 


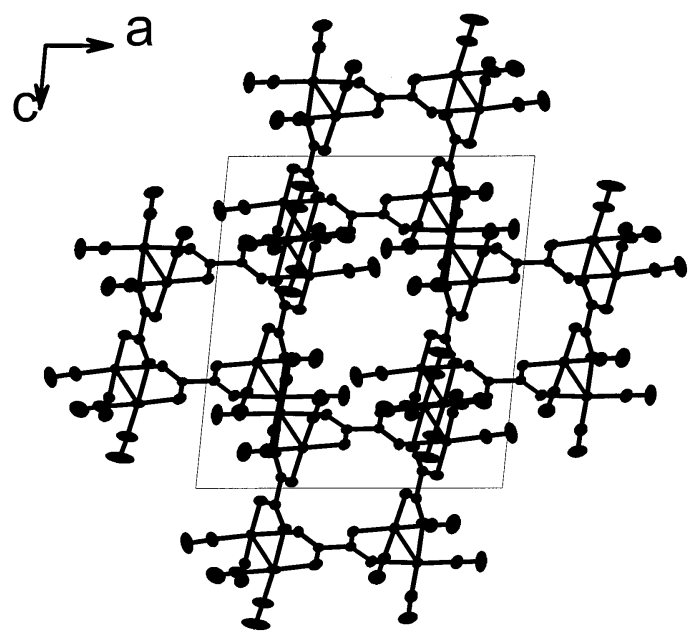

Figure 3. Packing diagram for the molecular square 2, viewed along the $b$ axis. All hydrogen atoms and the $\mathrm{PMe}_{3}$ groups on each Ru atom have been omitted for clarity.

atoms and two $\mathrm{C}$ atoms (i.e., $\mathrm{Ru}(2), \mathrm{C}\left(6^{\prime}\right), \mathrm{Ru}\left(1^{\prime}\right)$, and $C(6))$ in $\mathbf{1}$ and that of ca. $6.9 \times 6.9 \AA^{2}$ defined by four Ru atoms (i.e., $\mathrm{Ru}(1), \mathrm{Ru}\left(3^{\prime}\right), \mathrm{Ru}\left(2^{\prime}\right)$, and $\left.\mathrm{Ru}(4)\right)$ in $\mathbf{2}$. The singly bonded Ru-Ru distance (ca. $2.7 \AA$ ) forms the depth of the cage. The square area of ca. $7 \times 7 \AA^{2}$ was previously reported for $\left\{\left[\mathrm{MO}_{2}(\text { DaniF })_{2}\right]\left(\mu-\mathrm{O}_{2} \mathrm{CCO}_{2}\right)\right\}_{4} \cdot{ }^{3}$ Hence, the size of the square is apparently dictated by the type of rigid linear linkers, such as oxalate, used in 2 and $\left\{\left[\mathrm{MO}_{2}(\text { DaniF })_{2}\right]\left(u-\mathrm{O}_{2} \mathrm{CCO}_{2}\right)\right\}_{4}$. Single crystals of both $\mathbf{1}$ and $\mathbf{2}$ were grown from $\mathrm{CH}_{2} \mathrm{Cl}_{2}$ /hexane at ambient temperature, but only those of $\mathbf{2}$ were found to contain one disordered $\mathrm{CH}_{2} \mathrm{Cl}_{2}$ molecule within the square and two other molecules in intermolecular interstices. It should be noted that the molecular square $\left\{\left[\mathrm{Mo}_{2}(\text { DaniF })_{2}\right]\left(\mu-\mathrm{O}_{2} \mathrm{CCO}_{2}\right)\right\}_{4}$ has a "open" cage, but both $\mathbf{1}$ and $\mathbf{2}$ have phosphine-group-guarded cages. The size of the entrance into the cage is much smaller than that of $4.2 \times 4.2 \AA^{2}$ in $\mathbf{1}$ or that of $6.9 \times 6.9 \AA^{2}$ in $\mathbf{2}$, explaining why no solvent molecules were occluded into the cage in $\mathbf{1}$ during the single-crystal growing process. ${ }^{14}$

The crystal-packing patterns of compounds $\mathbf{1}$ and $\mathbf{2}$ are also interesting. Although the square holes found for 2 and for $\left\{\left[\mathrm{MO}_{2}(\text { DaniF })_{2}\right]\left(\mu-\mathrm{O}_{2} \mathrm{CCO}_{2}\right)\right\}_{4}$ are similar to each other in terms of the dimensions, the packing pattern adopted for $\mathbf{2}$ is different from that for $\left\{\left[\mathrm{MO}_{2}-\right.\right.$ (DaniF) $\left.\left.)_{2}\right]\left(u-\mathrm{O}_{2} \mathrm{CCO}_{2}\right)\right\}_{4}{ }^{3}$ For the Mo compound, the squares formed by the midpoint of the four $\mathrm{M}-\mathrm{M}$ axes stack directly on top of each other, creating a onedimensional tightly jointed channel. However, for $\mathbf{2}$, one square is piled above two corners of the two second squares, which are piled above two corners of the third square, as shown in Figure 3, creating a loose-jointed channel. Thus, it appears that all three $\mathrm{CH}_{2} \mathrm{Cl}_{2}$ solvent molecules in the unit cell, described above, are all within the square "channels" of the crystal. Although one might correlate the different packing habits with the different types of the building blocks, i.e., high-valent $\left\{\mathrm{Mo}_{2}-\right.$ $\left.(\text { DaniF })_{2}\right\}$ versus low-valent $\left\{\mathrm{M}_{2}(\mathrm{CO})_{4}\left(\mathrm{PR}_{3}\right)_{2}\right\}$, we do not

(14) (a) Takamizawa, S.; Mori, W.; Furihata, M.; Takeda, S.; Yamaguki, K. Inorg. Chim. Acta 1998, 283, 268. (b) Mori, W.; Takamigawa, S. J . Solid State Chem. 2000, 152, 120.
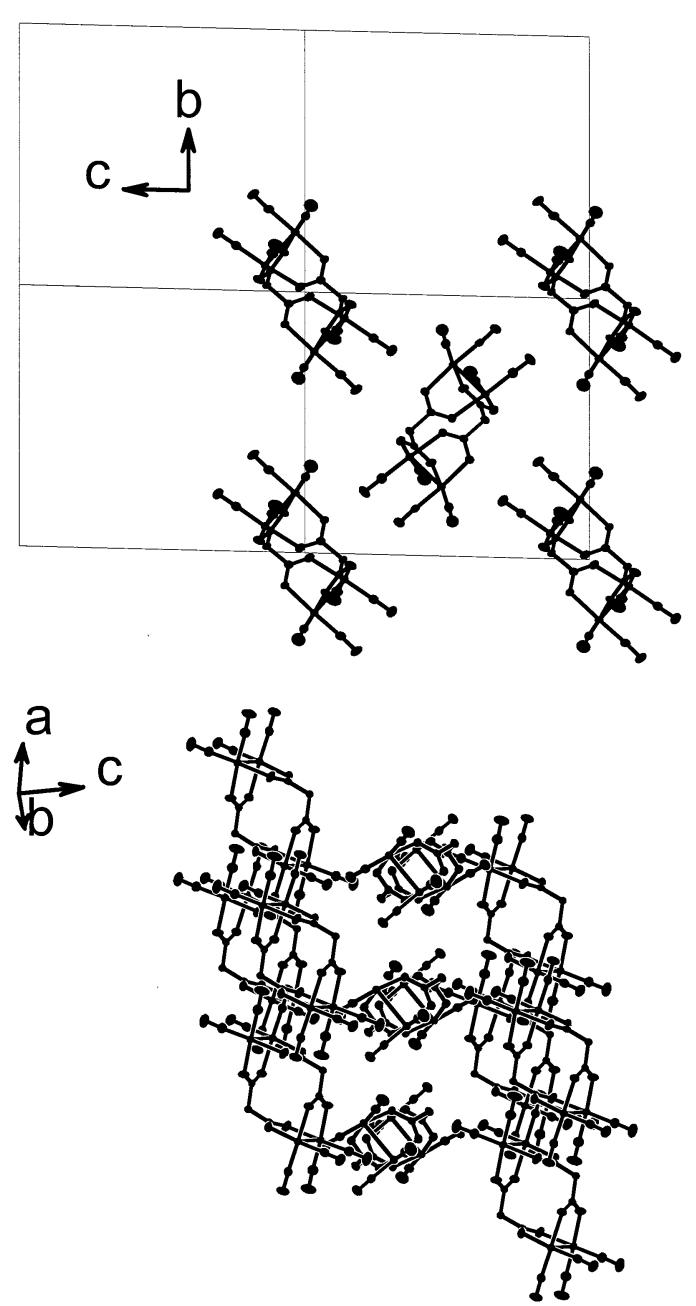

Figure 4. Packing diagrams for the molecular loop 1, viewed along ( $a$, top) the a axis and (b, bottom) the (120) direction. All hydrogen atoms and the $\mathrm{PMe}_{3}$ groups on each $\mathrm{Ru}$ atom have been omitted for clarity.

know the real reason for sure at the moment. Molecular loops $\mathbf{1 A}$ and $\mathbf{1 B}$ form two different stacks in the crystal 1. In a "face-centered" plane as viewed al ong the a axis (Figure 4a) $\mathbf{1 A}$ is located at the center position and $\mathbf{1 B}$ at the four corner positions. The two "square" planes for $\mathbf{1 A}$ and $\mathbf{1 B}$, defined above, are almost perpendicular to each other. The simplified skeletons with omitted hydrogen atoms and phosphine atoms for $\mathbf{1}$ appear to form channels (Figure 4b), but the empty space is partially blocked and filled by the omitted atoms. This explains why there are no solvent molecules found in the intermolecular interstices of crystal $\mathbf{1}$.

Acknowledgment. We thank the National Science Council of the Republic of China for financial support of this research (Contract No. NSC90-2113-M 006-021).

Supporting Information Available: Tables of atomic coordinates, thermal displacement coefficients, and all bond lengths and angles for $\mathbf{1}$ and 2; these data are al so available in $\mathrm{CIF}$ format. This material is available free of charge via the Internet at http://pubs.acs.org.

OM020360Q 